\title{
TARBAWI
}

Volume 4 No.1, Januari-Juni 2019

p-ISSN : 2527-4082, e-ISSN : 2622-920X

\section{Evaluasi Program Mutu Pelaksanaan Pembelajaran pada Tahapan Transactions (Suatu Pendekatan Model Stake's Countenance Evaluation)}

\author{
Program Quality Evaluation of Learning Implementation in the Transaction
} Stages (A Place for Stake's Countenance Evaluation Model)

\author{
Ferdinan $^{1}$, Nurhayati ${ }^{2}$ \\ ${ }^{*}$ ferdinan@unismuh.ac.id|Universitas Muhammadiyah Makassar \\ ${ }^{*}$ Universitas Negeri Tadulako Palu
}

\begin{abstract}
Abstrak
Penelitian ini adalah penelitian evaluasi dengan menggunakan jenis penelitian kombinasi (mixed methods). Pendekatan penelitian, yaitu: pendekatan studi kasus. Sumber data penelitian ini terdiri atas Rektor, Wakil Rektor I, Ketua Lembaga Penjaminan Mutu, Ketua Unit Penjaminan Mutu Fakultas, dan Kasubdit SDM Universitas dan yang menjadi responden yaitu 32 Ketua Prodi dan 70 Ketua Tingkat. Teknik pengumpulan data yaitu wawancara, studi dokumentasi, dan lembar observasi. Penilaian untuk setiap aspek evaluasi dikategorikan menjadi tiga tingkatan: tinggi, sedang, dan rendah. Pengambilan keputusan dikategorikan menjadi tiga tingkatan: tercapai, kurang tercapai, dan tidak tercapai. Penelitian evaluasi ini memberikan beberapa kesimpulan, yaitu gambaran pelaksanaan pembelajaran di Unismuh Makassar pada tahapan proses (transactions) menunjukkan bahwa: 1) penguasaan dosen dalam menyusun dan menyiapkan administrasi perkuliahan dari 7 subaspek yang dievaluasi terdapat 6 subaspek telah memenuhi kriteria objektif dan 1 subaspek yang kurang tercapai yaitu kemampuan dosen dalam menyusun buku ajar, 2)) penguasaan dosen dalam pelaksanaan perkuliahan menunjukkan bahwa dari 15 subaspek yang dievaluasi 13 subaspek sudah tercapai sesuai standar objektif dan 2 subaspek yang belum terpenuhi yaitu dosen tidak memberikan sanksi kepada mahasiswa yang terlambat 30 menit dalam mengikuti perkuliahan dan dosen belum menyampaikan materi kuliah dengan berbasis IT, 3) interaksi dosen dengan mahasiswa dalam perkuliahan, dari 4 subaspek yang dievaluasi semuanya telah memenuhi standar objektif, dan 4) kemampuan dosen dalam melakukan evaluasi hasil perkuliahan menunjukkan bahwa dari 12 subaspek yang dievaluasi terdapat 10 subaspek sudah tercapai sesuai standar objektif dan 2 subaspek kurang terpenuhi.
\end{abstract}

Kata Kunci: Evaluasi, Mutu Pembelajaran dan Transactions 


\begin{abstract}
This study is an evaluation study using mixed methods. Research approach, namely: case study approach. The data sources of this study consisted of the Chancellor, Deputy Chancellor I, Chairperson of the Quality Assurance Agency, Chair of the Faculty Quality Assurance Unit, and the Head of Sub-directorate of Human Resources of the University and respondents, namely 32 Chairmen of Study Programs and 70 Chairmen. Data collection techniques are interviews, documentation studies, and observation sheets. Assessments for each aspect of evaluation are categorized into three levels: high, medium, and low. Decision making is categorized into three levels: achieved, less achieved, and not achieved. This evaluation study provides several conclusions, namely the description of the implementation of learning in Unismuh Makassar at the stages of transactions shows that: 1) the mastery of lecturers in preparing and preparing lecture administration from 7 sub-aspects evaluated, there are 6 subaspects that meet objective criteria and 1 sub-aspect is lacking achieved, namely the ability of lecturers in preparing textbooks, 2)) mastery of lecturers in lecturing shows that out of $15 \mathrm{sub}$ aspects evaluated 13 sub-aspects have been achieved according to objective standards and 2 sub-aspects that have not been fulfilled, namely lecturers do not sanction students who are 30 minutes late in attending lectures and lecturers have not delivered IT-based lecture material, 3) lecturer and student interaction in lectures, of the 4 sub-aspects evaluated all met objective standards, and 4) lecturers' ability to evaluate lecture results showed that from 12 sub the evaluated aspects have 10 sub-aspects that have been achieved according to objective standards and 2 sub-aspects have not been fulfilled.
\end{abstract}

Keywords: Evaluation, Learning Quality and Transactions

PENDAHULUAN

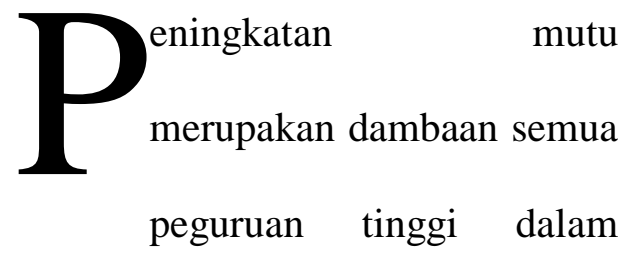

menyelenggarakan pendidikan.

Meningkatkan mutu perlu rumusan

pikiran tentang apa yang hendak

ditingkatkan, memilih bagian yang paling

dibutuhkan pelanggan, dan menghasilkan

produk kegiatan yang paling unggul di antara produk sejenis. Oleh karena itu,

peningkatan mutu memerlukan ide baru yang datang dari pikiran cerdas, selalu mengandung bagian yang berbeda dari yang ada sebelumnya, menghasilkan bagian yang lebih sempurna, lebih bermanfaat, lebih mempermudah sehingga lebih diminati.

Penjaminan mutu pendidikan formal, nonformal, dan informal 
Jurnal Tarbawi| Volume 4|No 1| p-ISSN : 2527-4082, e-ISSN : 2622-920X | 3

sebagaimana tersurat dalam Peraturan

Sistem Penjaminan Mutu

Menteri Pendidikan Nasional Nomor 63 Pendidikan, merupakan kegiatan yang

Tahun 2009 tentang sistem penjaminan sistemik dan terpadu pada

mutu pendidikan, bab I, pasal 3 ayat (2) penyelenggaraan pendidikan untuk

disebutkan bahwa penjaminan mutu meningkatkan tingkat kecerdasan

pendidikan dilakukan atas dasar prinsip: kehidupan bangsa. Kegiatan yang

1. Keberlanjutan; sistemik dan terpadu tersebut dilakukan

2. Terencana dan sistematis, dengan oleh satuan/program pendidikan, kerangka waktu dan target-target penyelenggara satuan/program capaian mutu yang jelas dan terukur pendidikan, pemerintah daerah, dalam penjaminan mutu pendidikan pemerintah pusat, dan masyarakat serta formal dan non formal; melibatkan dunia usaha.

3. Menghormati otonomi satuan Implementasi secara sistematis pendidikan formal dan nonformal; dan konsisten terhadap keempat tahap

4. Memfasilitasi pembelajaran informal tersebut merupakan esensi utama proses masyarakat berkelanjutan dengan penerapan Sistem Penjaminan Mutu yang regulasi Negara yang seminimal diamanatkan oleh Peraturan Menteri mungkin; $\quad$ Riset, Teknologi, dan Pendidikan No. 62

5. SPMP merupakan sistem terbuka yang Pasal 3 ayat (1) Tahun 2016 Tentang terus disempurnakan secara Sistem Penjaminan Mutu Pendidikan berkelanjutan. Tinggi yang terdiri atas Sistem Penjaminan Mutu Internal (SPMI) dan 
Sistem Penjaminan Mutu Eksternal Pendidikan. Standar Nasional pendidikan (SPME) atau akreditasi yang dilakukan mencakup: 1) Standar Isi; 2) standar oleh lembaga akreditasi.

Proses; 3)\Standar Kompetensi Lulusan;

Untuk menjamin mutu

4) Standar Pendidik dan Tenaga pendidikan, sebagaimana diamanatkan

Kependidikan; 5) Standar Sarana dan dalam UU Nomor 20 Tahun 2003 tentang

Prasarana; 6) Standar Pengelolaan; 7) Sisdiknas dan PP No. 32 Tahun 2013 Standar Pembiayaan Pendidikan; dan 8) tentang Standar Nasional Pendidikan Standar Penilaian. (SNP), kegiatan sistemik penjaminan Standar Nasional Pendidikan mutu penyelenggaraan pendidikan tinggi di perguruan tinggi oleh perguruan tinggi sendiri secara berkelanjutan (continuous improvement) perlu dilakukan.

Selanjutnya pemerintah melakukan akreditasi pada setiap jenjang pendidikan untuk menentukan kelayakan program dan atau satuan pendidikan. Apa yang menjadi esensi akreditasi adalah sebagai bentuk Akuntabilitas Publik yang dilakukan secara objektif, adil, transparan dengan menggunakan instrumen dan kriteria pada Standar Nasional Indonesia. 
Banyak masalah mutu yang akan menjadi beban masyarakat, dihadapi dalam dunia pendidikan, seperti menambah biaya kehidupan dan mutu lulusan, mutu pengajaran, kesejahteraan masyarakat, serta bimbingan dan latihan dari pendidik, serta memungkinkan menjadi warga yang mutu profesionalisme dan kinerja tersisih dari masyarakat.

pendidik. Mutu tersebut terkait dengan mutu manajerial para pimpinan pendidikan, keterbatasan dana, sarana dan prasarana, fasilitas pendidikan, media, sumber belajar, alat dan bahan latihan, lingkungan pendidikan, serta dukungan dari pihak-pihak yang terkait dengan pendidikan. Semua kelemahan mutu dari komponen-komponen pendidikan tersebut berujung pada rendahnya mutu lulusan. Mutu lulusan yang rendah dapat menimbulkan berbagai masalah, seperti tidak dapat bekerja/tidak diterima di dunia kerja, diterima bekerja, tetapi tidak berprestasi, tidak dapat mengikuti perkembangan masyarakat, dan tidak produktif. Lulusan yang tidak produktif

\section{Evaluasi program dikatakan} berhasil jika mencapai tujuan yang telah ditetapkan, melalui analisis perbandingan antara tujuan dan hasil yang dicapai. Keberhasilan program mencapai tujuan yang telah ditetapkan banyak dipengaruhi oleh berbagai faktor, yaitu faktor aspek masukan Antecedents), proses (transactions) dan hasil (outcomes) yang dapat dicermati dengan baik.

$$
\text { Berdasarkan permasalahan }
$$

tersebut di atas, maka perlu dilakukan penelitian secara mendalam berupa evaluasi program pelaksanaan kegiatan "penjaminan mutu"di Universitas Muhammadiyah Makassar. 


\section{METODE PENELITIAN}

Penelitian ini adalah penelitian

evaluasi dengan menggunakan jenis

penelitian kombinasi (mixed methods).

Pendekatan penelitian, yaitu: pendekatan

studi kasus. Sumber data penelitian ini

terdiri atas Rektor, Wakil Rektor I, Ketua

Lembaga Penjaminan Mutu, Ketua Unit

Penjaminan Mutu Fakultas, dan Kasubdit

SDM Universitas dan yang menjadi

responden yaitu 32 Ketua Prodi dan 70

Ketua Tingkat. Teknik pengumpulan data

yaitu wawancara, studi dokumentasi, dan

lembar observasi. Penilaian untuk setiap

aspek evaluasi dikategorikan menjadi tiga

tingkatan: tinggi, sedang, dan rendah.

Pengambilan keputusan dikategorikan

menjadi tiga tingkatan: tercapai, kurang

tercapai, dan tidak tercapai.

\section{PEMBAHASAN}

\section{A. Penguasaan Dosen dalam Menyusun dan Menyiapkan Administrasi Pembelajaran}

Tugas pokok dosen adalah mengajar dan mendidik yang meliputi memberi kuliah, praktikum, tutorial, pelatihan, dan evaluasi atau ujian, serta tugas pembelajaran lainnya kepada mahasiswa, sesuai dengan jenjang jabatan akademik dosen yang bersangkutan.

Dosen merupakan salah satu pekerjaan profesional. Pekerjaan profesional sebagai pendidik pada dasarnya bertitik tolak dari adanya panggilan jiwa, tanggung jawab moral, tanggung jawab sosial, dan tangggung jawab keilmuan. Kinerja seorang dosen merupakan suatu perilaku atau respon yang memberikan hasil untuk memacu apa yang mereka kerjakan. Kinerja dosen menyangkut semua aktivitas atau tingkah 
laku dalam mencapai suatu tujuan atau hasil perkuliahan. Hal ini tampak dari perilaku dosen dalam proses pembelajaran serta interaksi dosen dengan siswa.

$$
\text { Penguasaan dosen dalam }
$$

menyusun dan menyiapkan administrasi

perkuliahan yang dimaksud dalam penelitian ini adalah: (1) penyusunan

Silabus, Penyusunan RPS, Penyusunan

Buku Ajar, dan penyerahan dokumen (Silabus, RPS, dan Buku Ajar) ke Program Studi.

$$
\text { Untuk mencapai tujuan }
$$

pembelajaran dosen terlebih dahulu harus menyiapkan perangkat pembelajaran yang meliputi silabus, RPP dan buku ajar. Pelaksanaan pembelajaran dibutuhkan dosen yang memiliki pengetahuan, wawasan yang luas, serta metode yang bervariasi dalam meyampaikan materi pelajaran.

Hasil evaluasi dari 32 Program studi berkaitan dengan penguasaan dosen dalam menyusun dan menyiapkan administrasi perkuliahan diobservasi dengan menggunakan instrumen lembar observasi. Hasil jawaban observer dapat dilihat pada tabulasi skor berikut:

Tabel. 1

Tabulasi Skor Hasil Penilaian Observer terhadap Penguasaan Dosen dalam

\begin{tabular}{|c|c|c|c|c|c|c|c|c|c|}
\hline \multirow{2}{*}{ No } & \multirow{2}{*}{ Hal Yang Dinilai } & \multicolumn{4}{|c|}{ Rating } & \multirow{2}{*}{$\begin{array}{c}\text { Jumlah } \\
\text { Responden }\end{array}$} & \multirow{2}{*}{$\begin{array}{l}\text { Jml } \\
\text { Nilai }\end{array}$} & \multirow{2}{*}{$\begin{array}{c}\text { Nilai } \\
\text { Rata- } \\
\text { rata }\end{array}$} & \multirow{2}{*}{$\begin{array}{r}\text { Kate } \\
\text { gori }\end{array}$} \\
\hline & & 1 & 2 & 3 & 4 & & & & \\
\hline 1 & $\begin{array}{l}\text { Dosen Menyusun } \\
\text { Silabus Mata Kuliah }\end{array}$ & 0 & 0 & 6 & 26 & 32 & 122 & 3.81 & $\mathrm{~T}$ \\
\hline
\end{tabular}
Menyusun dan Menyiapkan Administrasi Perkuliahan 


\begin{tabular}{|l|l|l|l|l|l|l|l|l|l|}
2 & $\begin{array}{l}\text { Dosen Menyusun RPS } \\
\text { Perkuliahan }\end{array}$ & 0 & 9 & 23 & 32 & 119 & 3.71 & $\mathrm{~T}$ \\
\hline 3 & $\begin{array}{l}\text { Dosen Menyusun Buku } \\
\text { Ajar }\end{array}$ & 3 & 2 & 19 & 8 & 32 & 88 & 2.72 & $\mathrm{~S}$ \\
\hline 4 & $\begin{array}{l}\text { Dosen yang } \\
\text { perkuliahan Menyusun } \\
\text { mempertimbangkan } \\
\text { Perkembangan keilmuan } \\
\text { Jurusan }\end{array}$ & 0 & 5 & 13 & 14 & 32 & 105 & 3.28 & $\mathrm{~T}$ \\
\hline 5 & $\begin{array}{l}\text { Dosen menyerahkan } \\
\text { Silabus ke jurusan/prodi }\end{array}$ & 0 & 1 & 7 & 24 & 32 & 119 & 3.71 & $\mathrm{~T}$ \\
\hline 6 & $\begin{array}{l}\text { Dosen menyerahkan } \\
\text { RPS perkuliahan ke } \\
\text { Jurusan/prodi }\end{array}$ & 0 & 0 & 15 & 17 & 32 & 113 & 3.53 & $\mathrm{~T}$ \\
\hline 7 & $\begin{array}{l}\text { Dosen merevisi silabus } \\
\text { dan RPS setiap awal } \\
\text { semester }\end{array}$ & 0 & 4 & 6 & 22 & 32 & 114 & 3.56 & $\mathrm{~T}$ \\
\hline
\end{tabular}

Keterangan T = Tinggi (3, 01-4), S= Sedang (2, 01-3), dan R= Rendah (1-2)

Hasil analisis data instrumen Dari uraian di atas dapat observasi dari tabel di atas tentang disimpulkan, bahwa penguasaan dosen penguasaan dosen dalam menyusun dan dalam menyusun dan menyiapkan menyiapkan administrasi perkuliahan administrasi perkuliahan berada pada menunjukkan bahwa terdapat 6 kategori tinggi dengan nilai rata-rata 3,47. subkomponen yang berkategori tinggi Sedangkan dalam menyusun buku ajar atau memperoleh nilai rata-rata 3,49 dan belum sepenuhnya disusun oleh dosen 1 sub komponen berkategori sedang sesuai dengan ketentuan. Hal ini yang dengan nilai rata-rata 2,72. seharusnya menjadi perhatian oleh dosen- 
dosen di Universitas Muhammadiyah Makassar agar memperhatikan penyusunan buku ajar yang sangat penting karena dapat menjadi rujukan kerhasilan dalam mengajar.

Mekanisme penyusunan Rencana Program Semester (RPS) setiap mata kuliah dilakukan oleh kelompok dosen pengampu yang berada dalam satu bidang ilmu dengan tetap memperhatikan kompetensi, masukan dari dosen lain dan pengguna lulusan.

\section{Adapun program peningkatan}

wawasan dan keterampilan akademik dosen yang dilaksanakan pihak Unismuh Makasar yang diungkapkan oleh Ketua Lembaga Penjaminan Mutu Universitas Muhammadiyah Makassar (Quality Assurance), yaitu:

$$
\text { Peningkatan keterampilan }
$$

akademik dosen khususnya dosen baru adalah diwajibkan mengikuti Pelatihan peningkatan keterampilan dasar teknik instruksional (PEKERTI. Hal ini penting dilakukan sebab, biasanya bagi dosendosen yang bukan berlatar belakang pendidikan pasti ada kesulitan dalam melakukan pengajaran yang efektif dan efisien. "Oleh karena itu pelatihan Pekerti ini sangat penting untuk diikuti. Dengan pelatihan ini diharapkan cara pandang tenaga pendidik terhadap mahasiswanya bisa berubah menjadi lebih bernilai”.

Lebih lanjut diungkapkan pula bahwa:

Dalam rangka meningkatkan wawasan dosen tentang paradigma pembelajaran yang mendidik, perangkat pembelajaran yang operasional dan termasa (up to date), model-model pembelajaran inovatif dalam menyelenggarakan perkuliahan yang bermutu, Unismuh Makassar bekerjasama dengan Universitas Hasanuddin menyelenggarakan pelatihan Program Peningkatan Keterampilan Dasar Teknik Instruksional (PEKERTI) dan Applied Approach (AA). 
Pengembangan SDM dengan pepatah"sambil menyelam minum air". mengadakan pelatihan sesuai dengan Penguasaan terhadap ilmu atau mata kebutuhan akan meningkatkan kuliah yang diampunya harus merupakan pengetahuan dan keterampilan dosen persyaratan mutlak bagi seorang dosen dalam melaksanakan kerja dalam rangka ketika dijadwal kuliah. Kemampuan mencapai visi dan misi Universitas dosen dalam mengajar sesuai dengan Muhammadiyah Makassar. mata kuliah yang diampunya diharuskan

\section{B. Penguasaan Dosen Dalam} Perkuliahan di Universitas Muhammadiyah Makassar

Tugas dan tanggungjawab seorang dosen bukan hanya menyusun administrasi perkuliahan akan tetapi bagaimana menjalankan apa yang telah disusunnya. Penguasaan Dosen terhadap materi perkuliahan sebagai seorang profesional, sudah selayaknya menguasai materi perkuliahan yang diampunya. Seorang dosen harus memiliki spesialisasi yang jelas dalam penguasaan keilmuannya.Penguasaan suatu ilmu tidak bisa dilakukan seperti untuk memiliki kemampuan. Seorang dosen dituntut mampu melakukan pembelajaran yang jelas, benar, penuh kreativitas dan memiliki keinovasian dalam strategi pembelajaran.

Adapun evaluasi yang dilakukan berkaitan dengan penguasaan dosen dalam perkuliahan disusun instrumen lembar observasi untuk memudahkan pengambilan data hasil penelitian. Untuk lebih jelasnya evaluasi penguasaan dosen dalam pelaksanaan perkuliahan dapat dilihat dari hasil observasi yang dilakukan terhadap 32 Ketua Prodi, hal tersebut dapat dilihat pada tabel berikut: 
Tabel. 2

Tabulasi Skor Hasil Penilaian Observer terhadap Penguasaan Dosen dalam Pelaksanaan Perkuliahan

\begin{tabular}{|c|c|c|c|c|c|c|c|c|c|}
\hline \multirow{2}{*}{ No } & \multirow{2}{*}{ Hal Yang Dinilai } & \multicolumn{4}{|c|}{ Rating } & \multirow{2}{*}{$\begin{array}{c}\text { Jumlah } \\
\text { Responden }\end{array}$} & \multirow{2}{*}{$\begin{array}{l}\text { Jml } \\
\text { Nilai }\end{array}$} & \multirow{2}{*}{$\begin{array}{l}\text { Nilai } \\
\text { Rata- } \\
\text { rata }\end{array}$} & \multirow{2}{*}{$\begin{array}{l}\text { Kate } \\
\text { gori }\end{array}$} \\
\hline & & $\mathbf{1}$ & 2 & 3 & 4 & & & & \\
\hline 1 & $\begin{array}{l}\text { Dosen mengajar sesuai } \\
\text { dengan jadwal yang telah } \\
\text { ditetapkan }\end{array}$ & 0 & 0 & 15 & 17 & 32 & 113 & 3.53 & $\mathrm{~T}$ \\
\hline 2 & $\begin{array}{l}\text { Dosen menyampaikan } \\
\text { tata tertib perkuliahan } \\
\text { yang harus dipatuhi oleh } \\
\text { mahasiswa }\end{array}$ & 0 & 1 & 12 & 18 & 32 & 109 & 3.4 & $\mathrm{~T}$ \\
\hline 3 & $\begin{array}{l}\text { Dosen melakukan absensi } \\
\text { kehadiran mahasiswa } \\
\text { setiap pertemuan }\end{array}$ & 0 & 0 & 2 & 30 & 32 & 126 & 3.93 & $\mathrm{~T}$ \\
\hline 4 & $\begin{array}{l}\text { Keaktifan dosen dalam } \\
\text { memberikan perkuliahan }\end{array}$ & 0 & 0 & 4 & 28 & 32 & 116 & 3.62 & $\mathrm{~T}$ \\
\hline 5 & $\begin{array}{l}\text { Dosen memberikan } \\
\text { sanksi kepada mahasiswa } \\
\text { yang terlambat lebih dari } \\
30 \text { menit }\end{array}$ & 0 & 0 & 16 & 16 & 32 & 112 & 3.5 & $\mathrm{~T}$ \\
\hline 6 & $\begin{array}{l}\text { Dosen menyampaikan } \\
\text { tujuan perkuliahan yang } \\
\text { akan dicapai mahasiswa }\end{array}$ & 0 & 2 & 16 & 14 & 32 & 108 & 3.37 & $\mathrm{~T}$ \\
\hline 7 & $\begin{array}{l}\text { Dosen mengisi berita } \\
\text { acara perkuliahan dan } \\
\text { menandatanganinya }\end{array}$ & 0 & 0 & 4 & 28 & 32 & 116 & 3.62 & $\mathrm{~T}$ \\
\hline 8 & 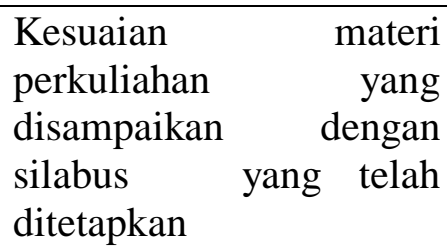 & 0 & 0 & 16 & 16 & 32 & 112 & 3.5 & $\mathrm{~T}$ \\
\hline 9 & $\begin{array}{l}\text { Dosen menyiapkan dan } \\
\text { menggunakan media }\end{array}$ & 0 & 0 & 21 & 11 & 32 & 107 & 3.34 & $\mathrm{~T}$ \\
\hline
\end{tabular}




\begin{tabular}{|l|l|l|l|l|l|l|l|l|l|} 
& $\begin{array}{l}\text { pembelajaran dalam } \\
\text { perkuliahan }\end{array}$ & & & & & & & \\
10 & $\begin{array}{l}\text { Materi yang diajarkan } \\
\text { dosen mudah dipahami }\end{array}$ & 0 & 2 & 19 & 11 & 32 & 105 & 3.28 & $\mathrm{~T}$ \\
\hline 11 & $\begin{array}{l}\text { Dosen menyampaikan } \\
\text { materi kuliah berbasis IT }\end{array}$ & 3 & 7 & 12 & 10 & 32 & 93 & 2.9 & $\mathrm{~S}$ \\
\hline 12 & $\begin{array}{l}\text { Dosen menggunakan } \\
\text { metode mengajar sesuai } \\
\text { dengan materi kuliah }\end{array}$ & 0 & 0 & 20 & 12 & 32 & 108 & 3.45 & $\mathrm{~T}$ \\
\hline 13 & $\begin{array}{l}\text { Dosen melakukan } \\
\text { pembelajaran yang } \\
\text { interaktif }\end{array}$ & 0 & 0 & 11 & 21 & 32 & 117 & 3.65 & $\mathrm{~T}$ \\
\hline 14 & $\begin{array}{l}\text { Dosen mengajar 16X } \\
\text { tatap muka di kelas }\end{array}$ & 0 & 0 & 12 & 20 & 32 & 116 & 3.62 & $\mathrm{~T}$ \\
\hline 15 & $\begin{array}{l}\text { Dosen memberikan } \\
\text { pertemuan tambahan jika } \\
\text { jumlah pertemuan belum } \\
\text { mencapai 16 tatap muka }\end{array}$ & 0 & 0 & 28 & 4 & 32 & & & \\
\hline
\end{tabular}

Keterangan: $\mathrm{T}=$ Tinggi $(3,1-4), \mathrm{S}=$ Sedang $(2,1-3)$, dan $\mathrm{R}=$ Rendah $\quad(0-2)$

Dari tabel di atas dapat diketahui berada di kategori sedang atau belum bahwa penguasaan dosen dalam sepenuhnya tercapai sesuai dengan efektifitas/ pelaksanaan perkuliahan standar objektif yang telah ditentukan, berdasarkan analisis lembar observasi yaitu dosen menyampaikan materi kuliah dari 15 subaspek yang dievaluasi berbasis IT dengan nilai rata-rata 2,9. menunjukkan capaian unit berkategori tinggi atau berada pada nilai rata-rata 3,44 dari 32 jawaban responden. Namun demikian terdapat 1 subaspek yang

\section{Interaksi Dosen dengan Mahasiswa} dalam Perkuliahan di Universitas Muhammadiyah Makassar 
Seorang dosen sudah selayaknya menguasai praktek-praktek pengajaran memiliki sosok pribadi yang hangat, yang berpusat pada tujuan dan menguasai positif dan konstruktif. Disinilah dituntut teknik-teknik pendekatan terhadap agar dosen memiliki kepribadian positif mahasiswa secara perorangan maupun terutama dalam cara berpikir dan bersikap kelompok yang terarah.

konstruktif. Dalam perkuliahan dosen senantiasa dituntut untuk menjalankan pelaksanaan perkuliahan yang di evaluasi tugas dan tanggungjawabnya secara di atas selanjutnya yang di evaluasi, yaitu profesional, begitu pula memiliki kompetensi sosial kepada mahasiswanya, dalam artian interaksi dosen dengan mahasiswa berjalan dengan penuh berkaitan dengan interaksi dosen dengan mahasiswa. Hasil observasi evaluasi ini diambil dari 32 Ketua Prodi. Hal tersebut dapat dilihat pada tabel berikut.

keakraban. Olehnya itu dosen perlu

Tabel. 3

Tabulasi Skor Hasil Penilaian Observer terhadap Interaksi Dosen dengan Mahasiswa dalam Perkuliahan

\begin{tabular}{|c|c|c|c|c|c|c|c|c|c|}
\hline \multirow{2}{*}{ No } & \multirow{2}{*}{ Hal yang dinilai } & \multicolumn{4}{|c|}{ Rating } & \multirow{2}{*}{$\begin{array}{c}\text { Jml } \\
\text { Responden }\end{array}$} & \multirow{2}{*}{$\begin{array}{l}\text { Jml } \\
\text { Nilai }\end{array}$} & \multirow{2}{*}{$\begin{array}{c}\text { Nilai } \\
\text { RataW- } \\
\text { rata }\end{array}$} & \multirow{2}{*}{$\begin{array}{l}\text { Kate } \\
\text { gori }\end{array}$} \\
\hline & & 1 & 2 & 3 & 4 & & & & \\
\hline 1 & $\begin{array}{l}\text { Kemampuan dalam } \\
\text { memotivasi mahasiswa } \\
\text { dalam pembelajaran }\end{array}$ & 0 & 2 & 7 & 23 & 32 & 117 & 3.65 & $\mathrm{~T}$ \\
\hline 2 & $\begin{array}{l}\text { Penggunaan bahasa dalam } \\
\text { pelaksanaan perkuliahan } \\
\text { (kejelasan dan sopan } \\
\text { santun dalam berbahasa) }\end{array}$ & 0 & 4 & 10 & 19 & 32 & 114 & 3.64 & $\mathrm{~T}$ \\
\hline
\end{tabular}




\begin{tabular}{|c|c|c|c|c|c|c|c|c|c|}
\hline 3 & $\begin{array}{l}\text { Dosen menerima saran } \\
\text { dan kritik dari mahasiswa } \\
\text { tentang upaya-upaya } \\
\text { perbaikan } \\
\text { pembelajaran. }\end{array}$ & 0 & 5 & 13 & 14 & 32 & 105 & 3.28 & $\mathrm{~T}$ \\
\hline 4 & $\begin{array}{lr}\text { Bersikap } & \text { kooperatif } \\
\text { menerima } & \text { pendapat } \\
\text { mahasiwa } & \text { dalam } \\
\text { berdiskusi } & \end{array}$ & 0 & 4 & 5 & 23 & 32 & 115 & 3.59 & $\mathrm{~T}$ \\
\hline & Jumlah & 0 & 15 & 35 & 79 & & 451 & 3.54 & $\mathrm{~T}$ \\
\hline
\end{tabular}

Keterangan: T= Tinggi (3, 01-4), S= Sedang (2, 01-3), dan R= Rendah (1-2)

Data di atas menunjukkan bahwa saat nilainya masih kurang atau dalam interaksi dosen dengan mahasiswa suatu tugas masih mendapat nilai yang berdasarkan hasil analisis 4 subaspek terkategori belum lulus menurut standar yang dievaluasi semuanya berkategori penilaian. Setiap penilaian yang tinggi atau dengan capaian nilai rata-rata dilakukan dosen harus adil, terbuka dan 3,54. Hal tersebut menunjukkan objektif. Pemberian Tugas dalam terpenuhinya semua standar objektif yang Perkuliahan Salah satu strategi dievaluasi. pembelajaran yang dapat dilakukan

\section{Kemampuan Dosen dalam} seorang dosen adalah dengan cara Melakukan Evaluasi Hasil pemberian tugas dalam perkuliahan. Perkuliahan

Pelaksanaan penilaian yang Tugas-tugas yang diberikan perlu dilakukan dosen harus objektif dan transparan. Mahasiswa harus tahu apakah mempertimbangkan kapasitas mahasiswa dalam melakukannya, waktu yang dibutuhkan dan bobot kesulitan dari mereka dapat melakukan remedial pada setiap tugas yang diberikan.Pemberian 
tugas dalam perkuliahan bukan suatu kompetensi peserta didik. Prosedur upaya mempersulit mahasiswa dalam evaluasi atau penilaian yang dilakukan belajar dan menyiksa mereka terutama sekaligus diintegrasikan ke dalam proses pada aspek waktu yang digunakan dan pembelajaran yang menyeluruh perlu pertimbangan aspek psikologis benar-benar dikuasai.

lainnya.Tugas-tugas dalam perkuliahan harus diberikan secara tepat, proporsional, bermanfaat, dan terjangkau oleh mahasiswa yang mengerjakannya.

Dosen perlu memiliki kemantapan dilakukan kegiatan pembelajaran. Untuk keterampilan dalam menyusun program lebih jelasnya dapat dilihat dari hasil pengajaran dan sekaligus program observasi yang dilakukan terhadap 32 penilaian yang berorientasikan pada ketua program studi sebagai berikut ini:

Tabel. 4

Tabulasi Skor Hasil Penilaian Observer terhadap Kemampuan Dosen dalam Melakukan Evaluasi Perkuliahan

\begin{tabular}{|c|c|c|c|c|c|c|c|c|c|}
\hline \multirow{2}{*}{ No } & \multirow{2}{*}{ Hal yang Dinilai } & \multicolumn{4}{|c|}{ Rating } & \multirow{2}{*}{$\begin{array}{c}\text { Jumlah } \\
\text { Responden }\end{array}$} & \multirow{2}{*}{$\begin{array}{c}\text { Jml } \\
\text { Nilai }\end{array}$} & \multirow{2}{*}{$\begin{array}{c}\text { Nilai } \\
\text { Rata- } \\
\text { rata }\end{array}$} & \multirow{2}{*}{$\begin{array}{l}\text { Kate } \\
\text { gori }\end{array}$} \\
\hline & & 1 & 2 & 3 & 4 & & & & \\
\hline 1 & $\begin{array}{l}\text { Dosen melaksanakan ujian } \\
\text { tengah semester sesuai } \\
\text { dengan waktu yang telah } \\
\text { ditetapkan/ kalender } \\
\text { akademik }\end{array}$ & 0 & 0 & 5 & 27 & 32 & 123 & 3.84 & $\mathrm{~T}$ \\
\hline 2 & $\begin{array}{l}\text { Dosen melaksanakan ujian } \\
\text { akhir semester sesuai } \\
\text { dengan waktu yang telah } \\
\text { ditetapkan/kalender } \\
\text { akademik }\end{array}$ & 0 & 0 & 12 & 20 & 32 & 116 & 3.62 & $\mathrm{~T}$ \\
\hline
\end{tabular}




\begin{tabular}{|c|c|c|c|c|c|c|c|c|c|}
\hline 3 & 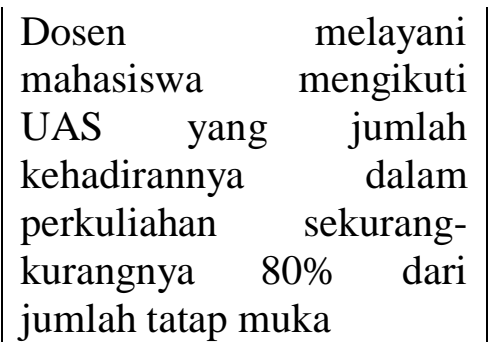 & 0 & 0 & 6 & 26 & 32 & 122 & 3.81 & $\mathrm{~T}$ \\
\hline 4 & \begin{tabular}{|lrr}
\multicolumn{2}{|c}{ Kesesuaian antara } & materi \\
yang diujikan & dengan \\
materi $\quad$ kuliah & yang \\
disampaikan & \\
\end{tabular} & 0 & 0 & 5 & 27 & 32 & 123 & 3.84 & $\mathrm{~T}$ \\
\hline 5 & $\begin{array}{|lr|}\text { Pengawasan } & \text { ujian } \\
\text { dilakukan langsung oleh } \\
\text { dosen pengampu mata } \\
\text { kuliah }\end{array}$ & 0 & 0 & 6 & 26 & 32 & 122 & 3.81 & $\mathrm{~T}$ \\
\hline 6 & $\begin{array}{l}\text { Transparansi dalam } \\
\text { penetapan nilai akhir dan } \\
\text { pengumuman nilai akhir } \\
\text { kepada mahasiswa }\end{array}$ & 0 & 2 & 15 & 15 & 32 & 107 & 3.34 & $\mathrm{~T}$ \\
\hline 7 & $\begin{array}{l}\text { Dosen memberikan ujian } \\
\text { susulan bagi mahasiswa } \\
\text { Peserta ujian yang tidak } \\
\text { hadir pada saat ujian } \\
\text { Akhir Semester dengan } \\
\text { alasan yang kuat }\end{array}$ & 0 & 0 & 14 & 18 & 32 & 114 & 3.56 & $\mathrm{~T}$ \\
\hline 8 & \begin{tabular}{|lrr}
\multicolumn{3}{l}{ Dosen penanggung jawab } \\
mata kuliah menentukan \\
waktu dan $r$ tempat \\
penyelenggaraan r ujian \\
susulan & \multicolumn{2}{r}{ selambat- } \\
lambatnya satu minggu \\
setelah & \multicolumn{2}{c}{ mahasiswa } \\
meminta ujian susulan
\end{tabular} & 0 & 0 & 10 & 22 & 32 & 118 & 3.68 & $\mathrm{~T}$ \\
\hline 9 & \begin{tabular}{lr}
\multicolumn{3}{|l}{ Dosen menyelenggarakan } \\
ujian ulang & bagi \\
mahasiswa & yang \\
memperoleh nilai D pada & semester yang baru \\
berjalan & \multicolumn{2}{r}{ selambat- } \\
lambatnya satu minggu \\
setelah nilai akhir mata \\
kuliah diumumkan
\end{tabular} & 0 & 0 & 17 & 15 & 32 & 114 & 3.45 & $\mathrm{~T}$ \\
\hline
\end{tabular}




\begin{tabular}{|c|c|c|c|c|c|c|c|c|c|}
\hline 10 & $\begin{array}{l}\text { Dosen menyelenggarakan } \\
\text { ujian ulang } \\
\text { mahasiswa bagi } \\
\text { memperoleh nilai E pada } \\
\text { semester yang baru } \\
\text { berjalan sang } \\
\text { lambatnya satu minggu } \\
\text { setelah nilai akhir mata } \\
\text { kuliah diumumkan }\end{array}$ & 2 & 20 & 5 & 5 & 32 & 77 & 2.4 & $\mathrm{~S}$ \\
\hline 11 & $\begin{array}{l}\text { Jika ada keberatan atas } \\
\text { nilai ujian, mahasiswa } \\
\text { peserta ujian dapat } \\
\text { menyampaikan keberatan } \\
\text { tersebut kepada dosen } \\
\text { penanggung jawab }\end{array}$ & 0 & 0 & 21 & 12 & 32 & 101 & 3.15 & $\mathrm{~T}$ \\
\hline 12 & $\begin{array}{l}\text { Obyektifitas } \\
\text { memberikan nilai kepada } \\
\text { mahasiswa }\end{array}$ & 1 & 0 & 17 & 14 & 32 & 108 & 3.58 & $\mathrm{~T}$ \\
\hline & Jumlah & 3 & 22 & 133 & 227 & & 1345 & 3.50 & $\mathrm{~T}$ \\
\hline
\end{tabular}

Keterangan: T= Tinggi (3, 01-4), $\mathrm{S}=$ Sedang (2, 01-3), dan $\mathrm{R}=$ Rendah (1-2)

tinggi atau berada pada nilai rata-rata 3.50

Dari tabel di atas dapat dilihat bahwa penguasaan dosen dalam melakukan penilaian berdasarkan hasil analisis adalah relevansinya berkategori tinggi dan pada setiap subaspek ditemukan ada 12 berkategori tinggi dan 1 berkategori sedang. Hasil analisis data observasi dari tabel di atas tentang penguasaan dosen dalam melakukan penilaian dengan capaian unit berkategori dari 12 subaspek yang dievaluasi.

Tujuan utama melaksanakan evaluasi dalam proses pembelajaran adalah untuk mendapatkan informasi yang akurat mengenai tingkat pencapaian tujuan instruksional oleh mahasiswa, sehingga tindak lanjut hasil belajar akan dapat diupayakan dan dilaksanakan. Melaksanakan penilaian proses pembelajaran merupakan bagian tugas 
dosen yang harus dilaksanakan setelah kegiatan pembelajaran berlangsung.

\section{PENUTUP}

Adapun kesimpulan dari penelitian ini yaitu:

1. Penguasaan dosen dalam menyusun dan menyiapkan administrasi perkuliahan dari 7 subaspek yang dievaluasi terdapat 6 subaspek telah memenuhi kriteria objektif dan 1 subaspek yang kurang tercapai yaitu kemampuan dosen dalam menyusun buku ajar.

2. Penguasaan dosen dalam pelaksanaan perkuliahan menunjukkan bahwa dari 15 subaspek yang dievaluasi 13 subaspek sudah tercapai sesuai standar objektif dan 2 subaspek yang belum terpenuhi yaitu dosen tidak memberikan sanksi kepada mahasiswa yang terlambat 30 menit dalam mengikuti perkuliahan dan dosen belum menyampaikan materi kuliah dengan berbasis IT.

3. Interaksi dosen dengan mahasiswa dalam perkuliahan, dari 4 subaspek yang dievaluasi semuanya telah memenuhi standar objektif, dan

4. Kemampuan dosen dalam melakukan evaluasi hasil perkuliahan menunjukkan bahwa dari 12 subaspek yang dievaluasi terdapat 10 subaspek sudah tercapai sesuai standar objektif dan 2 subaspek kurang terpenuhi

\section{DAFTAR PUSTAKA}

Arikunto, Suharsimi dan Cepi Safruddin Abdul Jabbar, Evaluasi Program Pendidikan. Pedoman Teoritis dan Praktis untuk Mahasiswa 
dan Praktisi Pendidikan (Jakarta: Bumi Aksara 2009)

Arikonto, Suharsimi. Dasar-Dasar Evaluasi Pendidikan (Jakarta: Bumi Aksara, 2009)

Boulmetis John dan Phyllis Dutwin, The ABCs of Evaluation: Timeless Techniques for Program and Project Managers (San Fransisco: A Wiley imprint, 2005)

B.Uno, Hamzah. Assessment Pembelajaran, (Jakarta: PT. Bumi Aksara, 2013), h. 3.

Daryanto, Evaluasi Pendidikan (Jakarta: Rineka Cipta, 2016), h. 14-15

Departemen Pendidikan Nasional, Kamus Besar Bahasa Indonesiat (Edisi ke empa; Jakarta: Pusat Bahasa, 2013)

Deviana Syuju'l, Muhammad, Implikasi Paedagogis Qs. Al-Hasyr Ayat 18 Tentang Dasar Teori Evaluasi Pendidikan Islam (Bandung, 13 Juli 2017)

Glasman, Naftaly S. dan David Nero Glasman, Evaluation in Decision Making: The Case of School Administration (North America, 1998)
Ibnu Rusn, Abidin. Pemikiran al-Gazali tentang Pendidikan (Yogyakarta: Pustaka Pelajar, 1998)

Purwanto, Ngalim Prinsip-Prinsip dan Teknik Evaluasi Pengajaran (Bandung: Remaja Rosda Karya, 2012), h. 5.

Poerbakawatja, Soegarda, Ensiklopedi Pendidikan (Jakarta: Gunung Agung, 1992)

Ramly, Mansyur, Mengukuhkan Peranan Lembaga Pendidikan dalam Mewujudkan Sumberdaya Manusia yang Berkualitas (Perspektif Islam), (Seminar Nasional, Unismuh Makassar, 30 Mei 2016

Republik Indonesia, Peraturan Pemerintah Nomor 23 Tahun 2013, Pasal 2 Tentang Standar Nasional Pendidikan.

Sallis, Edward. Total Quality Management in Education (London: Stylus Publishing Inc, 2002)

Sudijono, Anas, Pengantar Evaluasi Pendidikan (Jakarta: Rajawali Grafindo Persada, 2003)

Sutikno, Muzayanah. Evaluasi Program Pendidikan (Jakarta: PPS UNJ, 2009), h.1. 